\title{
The amphioxus genome sequence illuminates the evolutionary origin of vertebrates
}

\author{
Jeremy J. Gibson-Brown • Volker Hartenstein
}

Received: 1 October 2008 / Accepted: 9 October 2008 /Published online: 24 October 2008

(C) Springer-Verlag 2008

Keywords Amphioxus · Genome $\cdot$ Vertebrate $\cdot$ Evolution Cephalochordate

Amphioxus, ${ }^{1}$ also known as lancelets, are small, translucent, worm-like marine invertebrates (see cover) that spend most of their lives buried in the sea floor, filter-feeding through their jawless, ciliated mouths. Originally described as a type of mollusk - specifically, a type of sea slug - by Peter Simon Pallas in 1774, they were later reclassified as fish by Gabrielle Costa (1834) and William Yarrell (1836) who independently recognized their vertebrate-like features. These include a hollow neural tube dorsal to the gut, a notochord, a perforated pharyngeal region, a segmented body musculature (embryologically derived from somites), and a postanal tail. In 1886, the great Russian embryologist - and supporter of Darwin-Alexander Kowalevsky, observed that, unlike other vertebrates, amphioxus had an early embryology that was very similar to that of certain invertebrates, planting the seeds of the idea that this animal might represent a key "missing link" between vertebrates and

$\overline{1}$ phylum Chordata: subphylum Cephalochordata=Acrania.

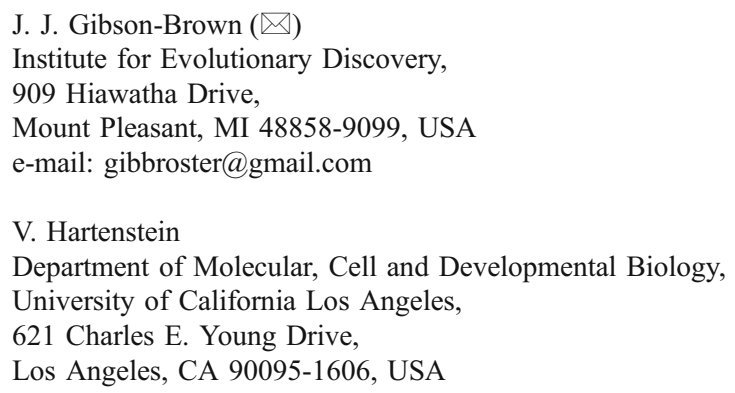

invertebrates (Kowalevsky 1886). These, and other studies of amphioxus morphology and development (e.g., Lankester and Willey 1890; Willey 1894; Conklin 1932; Herdman 1904; Goodrich 1909), convincingly demonstrated that vertebrates arose from a particular group of marine invertebrates, effectively uniting two primary divisions within the animal kingdom. Together, the vertebrates, urochordates (ascidians), and cephalochordates constitute the phylum Chordata, all descended from a common ancestor that lived more than 550 mya in the Precambrian period.

Absent any understanding of the genetic programs regulating developmental processes, no further progress could be made, so it took another 100 years before the advent of molecular-biological technologies allowed any connection to be established between the developmental mechanisms employed by vertebrates and invertebrates. Then, in 1984, a paper appeared showing that certain DNA-binding transcription factors previously implicated in the determination of anterior/posterior body parts in flies-encoded by Hox genes-were also present in vertebrates, including humans (McGinnis et al. 1984). This realization represented a true "paradigm shift" in our understanding of the genetic connectedness between all bilaterally symmetrical animals (bilaterians), one that could never have been imagined by Darwin or his advocates 150 years earlier.

About 20 years ago, an extraordinary coincidence occurred. Having been characterizing Hox genes in mice as a graduate student (Krumlauf et al. 1987; Holland 1988; Holland and Hogan 1988a,b), Peter Holland, then a research fellow in the Department of Zoology at Oxford University, became interested in how Hox gene expression patterns might inform our understanding of homologies between the 
body parts of vertebrates and invertebrates and had the idea that by examining Hox gene expression patterns during amphioxus embryogenesis, this longstanding impasse might finally be breached. Unbeknownst to him, on the other side of the Atlantic, Nick and Linda Holland at the Scripps Institution of Oceanography in San Diego had come to exactly the same conclusion! Having figured out that electric shocks could induce ripe adults to spawn in the laboratory (Holland and Holland 1989), Nick and Linda had begun studying amphioxus embryogenesis to gain insights into the evolutionary origins of vertebrates and concluded that studying Hox gene expression in amphioxus embryos could lead to a better understanding of the homologies of body parts between amphioxus and vertebrates. At this point, aware of their similar interests, Thurston Lacalli at the University of Saskatchewan, Canada, put Peter in touch with his American namesakes. Peter had originally proposed to work on both the British (B. lanceolatum) and Floridian (B. floridae) species, but the new team collectively decided to focus on the Florida amphioxus because it could be collected more conveniently and readily induced to spawn in the laboratory. The Americans quickly sent DNA to Peter and his student, Nic Williams, so they could start cloning and sequencing amphioxus Hox genes. In March of 1992, Linda joined Peter in Oxford where they adapted established, nonradioactive RNA in situ hybridization methods to determine the developmental expression domains of amphioxus Hox 3, which, with the typical Englishman's appreciation of a good pun, Peter christened AmphiHox3.

As a consequence of this remarkable intellectual convergence, a new field was effectively born, the "moleculardevelopmental biology of amphioxus." Its landmark product was a paper that concluded that the vertebrate brain did not evolve de novo, anterior to the neural structures of a cephalochordate-like ancestor - an issue long debated upon morphological grounds (see Gans and Northcutt 1983) but rather from the elaboration of a preexisting, prespecified, anterior neural region (Holland et al. 1992).

Since then, much light has been shed on the evolution of vertebrate developmental programs and their derived structures by studying the expression of key developmental genes in amphioxus, particularly with regard to the evolution of the central nervous system and rostrocaudal patterning processes (reviewed by Holland et al. 1996; Holland and Holland, 1999; Holland, 2000, 2002; Holland and Chen 2001; Holland and Takahashi 2005). Characterization of the amphioxus Hox cluster (Garcia-Fernández and Holland 1994), in particular, highlighted the central role of amphioxus as an essential model organism for understanding the evolutionary origins of vertebrate genomes and the developmental programs they encode.

Following the publication of the human and mouse genomes, the availability of whole-genome sequencing technologies prompted one of us (JJGB)-in collaboration with Linda Holland and others (Gibson-Brown et al. 2003) to propose that the logical next step would be to obtain the complete amphioxus genome sequence, both to understand the evolutionary origins of vertebrate genome sequences and to provide an essential resource for the study of individual genes in the evolution of vertebrate genetic programs. Happily, this effort recently culminated in the publication of the Branchiostoma floridae genome sequence in the journal Nature by Putnam et al. (2008). In companion papers published in Genome Research, initial analyses of the evolutionary, developmental, and physiological implications of the new data were also presented (Holland et al. 2008; Yu et al. 2008a).

To celebrate this occasion, and to provide an additional forum for the presentation of novel insights into the biology of amphioxus and vertebrate evolution made possible by the availability of the amphioxus genome sequence (Putnam et al. 2008), we here present a number of contemporaneous papers submitted by most of the principal laboratories engaged in amphioxus research worldwide.

The first paper, from the laboratories of Hidetoshi Saiga and Peter Holland (Takatori et al. 2008), presents the most comprehensive survey and classification of homeobox genes in the amphioxus genome possible to date, thereby characterizing the basal chordate complement of Hox genes and providing an invaluable resource for the future classification of any homeodomain-encoding gene isolated from any chordate genome. The second, from the laboratory of Jordi Garcia-Fernàndez, explores how the unexpectedly large number of conserved noncoding regions detected within the amphioxus and vertebrate Hox clusters provides a baseline for exploring the evolution of Hox gene regulation within the ancestral chordate Hox cluster and its vertebrate derivatives (Pascual-Anaya et al. 2008). Linda Holland and colleagues then exploit the genome sequence to explore how the many genes previously implicated in vertebrate and invertebrate segmentation can provide new insight into the evolution of chordate somitogenesis and vertebrate segmentation processes (Beaster-Jones et al. 2008). Next, several laboratories unite to present an interdisciplinary exploration of how comparative genomic, genetic, and developmental expression analyses can further our understanding of the evolutionary origins of novel morphological features; in this case, the evolutionary origins of vertebrate limbs (Horton et al. 2008).

These papers are followed by several studies that, like the first, use the newly available amphioxus genome sequence to characterize the basal complement of chordate developmental genes and provide a framework for the characterization of their homologs in other chordates. In the first of these, the amphioxus complement of Fox geneswhich encode DNA-binding transcription factors contain- 
ing a winged-helix, fork-head domain - is characterized (Yu et al. 2008b). Sebastian Shimeld (2008) then presents a similar analysis for the $\mathrm{C} 2 \mathrm{H} 2$ family of zinc finger genes. In a short communication, Satou et al. (2008) confirm previous reports that the ancestral chordate genome contained essentially the same repertoire of regulatory genes as those of vertebrates, but fewer genes.

From the laboratory of Vincent Laudet, Schubert et al. (2008) characterize the nuclear hormone receptor signaling pathways in amphioxus, and Paris et al. (2008) examine how the genome sequence enlightens the evolutionary origins of thyroid hormone signaling pathways in vertebrates. In the same vein, Ricard Albalat (2008) exploits the genome sequence to characterize the chordate origins of the DNA-methylation machinery later recruited into the epigenetic modification of developmental programs in amniotes, and Wang et al. (2008) explore the evolutionary origins of creatine metabolism at the invertebrate/vertebrate transition. Additionally, the important issue of similarities in gene expression between the well-characterized B. floridae and Mediterranean $B$. lanceolatum - an emerging model system in the laboratory of Hector Escriva at Banyuls-sur-Mer, France-is explored and reassuringly confirms that the information obtained over the past 20 years in the Florida species will be directly applicable to future studies in the latter (Somorjai et al. 2008).

As important as any of the original articles presented in this issue, indeed, on par with the publication of the genome sequence itself, is the announcement here, in a technical note, of a cDNA resource for $B$. floridae by $\mathrm{Yu}$ et al. (2008c). This group presents the large-scale generation of $5^{\prime}$ and $3^{\prime}$ EST sequences for around 140,000 cDNA clones, derived from five key developmental stages, used to validate the gene models predicted from the amphioxus genome sequence by Putnam et al. (2008). The cDNA clones obtained have been grouped into 21,229 cDNA clusters, each corresponding to a unique transcript species from $B$. floridae. A searchable database for this EST dataset has also been created (http://amphioxus.icob.sinica.edu.tw/), and all of the original 140,000 cDNA clones are publicly available upon request.

In conclusion, after more than 230 years of research, the year 2008 marks a watershed in our ability to understand the key genomic and (ergo) genetic changes that led to the evolution of vertebrate organs, tissues, and cells from those in their invertebrate ancestors. Like all of us in the resurgent field of Evolutionary Developmental Biology ("Evo-Devo"), Kowalevski and Darwin would be delighted!

Acknowledgements We are greatly indebted to Nick and Peter Holland for their insights into the history of amphioxus research.

\section{References}

Albalat R (2008) Evolution of DNA methylation machinery: DNA methyltransferases and methyl-DNA binding proteins in the amphioxus Branchiostoma floridae. Dev Genes Evol. doi:10.1007/s00427-008-0247-7

Beaster-Jones L, Kaltenbach SL, Koop D, Yuan S, Chastain R, Holland LZ (2008) Expression of somite segmentation genes in amphioxus: a clock without a wavefront? Dev Genes Evol. doi:10.1007/s00427-008-0257-5

Conklin EG (1932) The embryology of amphioxus. J Morph 54:69-151

Costa OG (1834) Cenni zoologici ossia descrizione sommaria delle specie nuove di znimali discoperti in diverse contrade del regno nell'anno 1834. Azzolino, Naples

Gans C, Northcutt RG (1983) Neural crest and the origin of vertebrates: a new head. Science 220:268-273

Garcia-Fernández J, Holland PWH (1994) Archetypal organization of the amphioxus Hox gene cluster. Nature 370:563-566

Gibson-Brown JJ, Osoegawa K, McPherson JD, Waterston RH, De Jong PJ, Rokhsar DS, Holland LZ (2003) A proposal to sequence the amphioxus genome submitted to the Joint Genome Institute of the US Department of Energy. J Exp Zoolog B Mol Dev Evol 300:5-22

Goodrich ES (1909) On the structure of the excretory organs of amphioxus. Quart J Micro Sci 54:185-205

Herdman WA (1904) Ascidians and amphioxus. In: Harmer SF, Shipley HE (eds) The Cambridge natural history, vol. 7, 1st edn. Macmillan, London, pp 135-138

Holland PWH (1988) Homeobox genes and the vertebrate head. Development 103(Suppl):17-24

Holland LZ (2000) Body plan evolution in the Bilateria: early anteroposterior patterning and the deuterostome-protostome dichotomy. Curr Opin Genet Dev 10:434-442

Holland LZ (2002) Heads or tails? Amphioxus and the evolution of anterior-posterior patterning in deuterostomes. Dev Biol 241:209-228

Holland PWH, Hogan BLM (1988a) Spatially restricted patterns of expression of the homeobox-containing gene Hox 2.1 during mouse embryogenesis. Development 102:159-174

Holland PWH, Hogan BLM (1988b) Expression of homeo box genes during mouse development: a review. Genes Dev 2:773-782

Holland ND, Holland LZ (1989) Fine structural study of the cortical reaction and formation of the egg coats in a lancelet (=amphioxus), Branchiostoma floridae (phylum Chordata: subphylum Cephalochordata=Acrania). Biol Bull 176:111-122

Holland LZ, Holland ND (1999) Chordate origins of the vertebrate central nervous system. Curr Opin Neurobiol 9:596-602

Holland ND, Chen J (2001) Origin and early evolution of the vertebrates: new insights from advances in molecular biology, anatomy, and palaeontology. BioEssays 23:142-151

Holland PWH, Takahashi T (2005) The evolution of homeobox genes: implications for the study of brain development. Brain Res Bull 66:484-490

Holland PWH, Holland LZ, Williams NA, Holland ND (1992) An amphioxus homeobox gene: sequence conservation, spatial expression during development and insights into vertebrate evolution. Development 116:653-661

Holland LZ, Holland PWH, Holland ND (1996) Revealing homologies between body parts of distantly related animals by in situ hybridization to developmental genes: amphioxus vs vertebrates. In: Ferraris JD, Palumbi SR (eds) Molecular zoology: advances, strategies and protocols. Wiley, Chichester, pp 267-282

Holland LZ, Albalat R, Azumi K, Benito-Gutiérrez E, Blow MJ, Bronner-Fraser M, Brunet F, Butts T, Candiani S, Dishaw LJ, Ferrier DE, Garcia-Fernàndez J, Gibson-Brown JJ, Gissi C, 
Godzik A, Hallböök F, Hirose D, Hosomichi K, Ikuta T, Inoko H, Kasahara M, Kasamatsu J, Kawashima T, Kimura A, Kobayashi M, Kozmik Z, Kubokawa K, Laudet V, Litman GW, McHardy AC, Meulemans D, Nonaka M, Olinski RP, Pancer Z, Pennacchio LA, Pestarino M, Rast JP, Rigoutsos I, Robinson-Rechavi M, Roch G, Saiga H, Sasakura Y, Satake M, Satou Y, Schubert M, Sherwood N, Shiina T, Takatori N, Tello J, Vopalensky P, Wada $\mathrm{S}$, Xu A, Ye Y, Yoshida K, Yoshizaki F, Yu JK, Zhang Q, Zmasek CM, de Jong PJ, Osoegawa K, Putnam NH, Rokhsar DS, Satoh N, Holland PWH (2008) The amphioxus genome illuminates vertebrate origins and cephalochordate biology. Genome Res 18:1100-1111

Horton AC, Mahadevan NR, Minguillon C, Osoegawa K, Rokhsar DS, Ruvinsky I, de Jong PJ, Logan MP, Gibson-Brown JJ (2008) Conservation of linkage and evolution of developmental function within the $T b \times 2 / 3 / 4 / 5$ subfamily of T-box genes: implications for the origin of vertebrate limbs. Dev Genes Evol. doi:10.1007/ s00427-008-0249-5

Kowalevsky A (1866) Entwicklungsgeschichte des Amphioxus lanceolatus. Mém Acad Imp Sci St-Pétersbg 11:1-17

Krumlauf R, Holland PW, McVey JH, Hogan BL (1987) Developmental and spatial patterns of expression of the mouse homeobox gene, Hox 2.1. Development 99:603-617

Lankester ER, Willey AQ (1890) The development of the atrial chamber of amphioxus. Quart J Micro Sci 31:445-466

McGinnis W, Garber RL, Wirz J, Kuroiwa A, Gehring WJ (1984) A homologous protein-coding sequence in Drosophila homeotic genes and its conservation in other metazoans. Cell 37:403-408

Pallas PS (1774) Spicilegia Zoologica, quibus novae imprimus et obscurae animalium species iconibus, descriptionibus atque commentariis illustrantur. Tomus 1, Fasciculos Decem. Lange, Berlin

Paris M, Brunet F, Markov GV, Schubert M, Laudet V (2008) The amphioxus genome enlightens the evolution of the thyroid hormone signaling pathway. Dev Genes Evol. doi:10.1007/ s00427-008-0255-7

Pascual-Anaya J, D'Aniello S, Garcia-Fernàndez J (2008) Unexpectedly large number of conserved non-coding regions within the ancestral chordate Hox cluster. Dev Genes Evol. doi:10.1007/ s00427-008-0246-8

Putnam NH, Butts T, Ferrier DEK, Furlong RF, Hellsten U, Kawashima T, Robinson-Rechavi M, Shoguchi E, Terry A, Yu J-K, Benito-Gutiérrez È, Dubchak I, Garcia-Fernàndez J, GibsonBrown JJ, Grigoriev IV, Horton AC, de Jong PJ, Kapitonov V, Kohara Y, Kuroki Y, Lindquist E, Lucas S, Osoegawa K,
Pennacchio LA, Salamov AA, Satou Y, Sauka-Spengler T, Schmutz J, Shin-I T, Toyoda A, Bronner-Fraser M, Fujiyama A, Holland LZ, Holland PWH, Satoh N, Rokhsar DS (2008) The amphioxus genome and the evolution of the chordate karyotype. Nature 453:1064-1071

Satou Y, Wada S, Sasakura Y, Satoh N (2008) Regulatory genes in the ancestral chordate genomes. Dev Genes Evol. doi:10.1007/ s00427-008-0219-y

Schubert M, Brunet F, Paris M, Bertrand S, Benoit G, Laudet V (2008) Nuclear receptor signaling in amphioxus. Dev Genes Evol. doi:10.1007/s00427-008-0251-y

Shimeld SM (2008) C2H2 zinc finger genes of the Gli, Zic, KLF, SP, Wilms Tumour, Huckebein, Snail, Ovo, Spalt, Odd, Blimp-1, Fez and related gene families from Branchiostoma floridae. Dev Genes Evol. doi:10.1007/s00427-008-0248-6

Somorjai I, Bertrand S, Camasses A, Haguenauer A, Escriva H (2008) Evidence for stasis and not genetic piracy in developmental expression patterns of Branchisotoma lanceolatum and Branchiostoma floridae, two amphioxus species that have evolved independently over the course of 200 Myrs. Dev Genes Evol. doi:10.1007/s00427-008-0256-6

Takatori N, Butts T, Candiani S, Pestarino M, Ferrier DEK, Saiga H, Holland PWH (2008) Comprehensive survey and classification of homeobox genes in the genome of amphioxus, Branchiostoma floridae. Dev Genes Evol. doi:10.1007/s00427-008-0245-9

Yarrell W (1836) A history of British fishes, vol. 2, 1st edn. Van Voorst, London

Yu J-K, Meulemans D, McKeown SJ, Bronner-Fraser M (2008a) Insights from the amphioxus genome on the origin of vertebrate neural crest. Genome Res 18:1127-1132

Yu J-K, Mazet F, Chen Y-T, Huang S-W, Jung K-C, Shimeld SM (2008b) The Fox genes of Branchiostoma floridae. Dev Genes Evol. doi:10.1007/s00427-008-0229-9

Yu J-K, Wang M-C, Shin-I T, Kohara Y, Holland LZ, Satoh N, Satou $\mathrm{Y}(2008 \mathrm{c})$ A cDNA resource for the cephalochordate amphioxus Branchiostoma floridae. Dev Genes Evol. doi:10.1007/s00427008-0228-X

Wang L, Chen D, Zhang Y, Lin Y, Li J, Zhang H (2008) Characterization of AGAT, GAMT and CT1 in amphioxus: implications for the evolutionary conservation of creatine metabolism related molecules at the invertebrate-to-vertebrate transition. Dev Genes Evol. doi:10.1007/s00427-008-0241-0

Willey A (1894) Amphioxus and the ancestry of the vertebrates. Macmillan, New York 